\title{
Research of Urban Regeneration Strategy of the Northern Chengdu Renovation District -A Case of Simaqiao District
}

\author{
Yanchuan Mou, Ang Hu \\ College of Architecture \& Environment, Sichuan University, Chengdu, Sichuan Province, China
}

\begin{abstract}
Because of limited conditions, way of removing old buildings then rebuilding by large area was difficult to carry out in northern Chengdu renovation district, so had to explore the new old city renovation mode dominated by urban regeneration. Taking Simaqiao district as an example and combining its historical date and investigation, finally urban regeneration strategies are put forward from four aspects, including teasing urban tissue \& building urban axis, optimizing the space structure \& extending the space form, leveraging economic leverages of urban regeneration and persueing tiny cycle renovation mode.
\end{abstract}

Index Terms - Urban Regeneration, Relieved and Safe City, PFI, BOT, Tiny Cycle Renovation

\section{Introduction}

In recent years, eastern and southern Chengdu gets a good development, by contrast, northern Chengdu develops slowly. On the one hand, because of the existence of Chengdu Railway Station, many professional wholesale market and logistic companies are gathered here, so the industry formats is low-level. At the same time, reasons such as incomplete road pattern, rough pavement and lacking of parking facilities also lead the northern Chengdu having mixed people and heavy traffic and chaos public security. On the other hand, because most of the northern buildings were built in the early Founding and the early Reformed Opening Up, so the form is old and the density is great. Once bustling northern Chengdu now becomes scared, its full load even overload operation brings the development of the city enormous presure and obstacles. In this context, Chengdu launched "Northern Chengdu" project in 2012, involved about land of 195 square kilometers, population of 1.5 million. Jinniu district involves about land of 85 square kilometers and population of 0.85 million, as the largest involved land and most involved population district in "Northern Chengdu "project ,its revolution work is very tough .

Jinniu district's renovation planning structure is "four axises \& eight pieces ".Four axises are city-out loads of Jinniu district, such as the old Chengdu-Dujiangyan Road, Jiaotong University Road, People North Road, Sichuan-Shanxi Road and Jiefang Road. Eight pieces are almost covered the whole district. Among the pieces, Jiefang Road--Caojia Alley piece crosses Chengdu First and Second Ring Road and belongs to the city center. Because of many reasons ,such as a amount of built-earlier buildings there, great residential density, populated traditional markets and gathered floating population and so on, all the reasons make the renovation work particularly difficult. The most common way of old city renovation that dominated by real estate development, demolish -rebuilt on a large scale doesn't have conditions there. According to introduction, this kind of renovation accounts for about $90 \%$ to the whole renovation work in Jinniu district, so to explore new old city renovation mode is imperative.

Under this background, entrusted by Jinniu district Planning Branch, we take Simaqiao district as an example to study how to finnish its old city renovation, and finally put forward that Jinniu district should take the new old city renovation mode dominated by urban regeneration. As another possible way of old city renovation, urban regeneration is to split the city into many small pieces, then on a small scale for maintenance, revolution and demolition, and gradually restore function and vitality of the city. The mode can not only alleviate many contradictions in old city renovation, but also effectively sustain the cultural vein and preserve the city space form.

\section{Simaqiao District History and Present}

\section{A. Overview}

Simaqiao district is one part of Jinniu community, being rich in history and culture. Sima is named after Xiangru Sima's inscription in Shahe bridge "Won't cross the bridge, unless being wealthy by taking four-horse bonzer carriage", which is no longer exists on the river now, but its name is still used and being a witness of the history of Chengdu. Simaqiao district is located in the north gate of Chengdu, which is an important passage out of the city. Simaqiao district crosses Chengdu First and Second Ring Road, its area is 2.79 square kilometers, of which approximately 1.12 square kilometers within Chengdu First Ring Road, approximately 1.18 square kilometers between Chengdu First and Second Ring Road.

\section{B Road and River}

Jiefang Road is north-south trunk road crossing the main crosses in Chengdu First and Second Ring Road. The name of Jiefang Road dates back to December 29, 1949, the date of the PLA troops celebrated the liberatation in Chengdu by driving more than 30 cars. Later, to commemorate the matter, the road which the troops went through from Simaqiao to Wuhouci is named for Jiefang Road. Being a main road axis in this area, today's Jiefang Road is serious damaged because of its too heavy traffic. In addition, the building facade is unbearable to see and the shops's billboards are stale and messy. Urban style is need to be improved. 
Chengdu is located in Minjiang River area and Tuojiang River area. The tributaries in old town like a network. On the history of Simaqiao district, there are two old agricultural irrigation canals named Shengxi River and Zhuantouyan River. With the transformation of the industrial structure, the old irrigation canals gradually lost its industrial capabilities, being malodorous and contamination, then slowly turned into the city's sewers. To alleviate the contradiction, the government ordered relevent department to cement board on irrigation canals, then plant plants on them. The traces of past irrigation canals can only be looked for in several dry bridges in this area.

\section{Architectural Form}

Multi-story buildings in Simaqiao district mostly were built in the early Reformed Opening Up and most of them are residential buildings, with large building density, and volume rate is higher than the average of 2.5. Taking Sichuan Construction community located at the east of Maan Road as an example, it is built in the eighties of last century and it is six-story brick structure housing. Its building facades are serious damaged, and it's common to see that the first floor of the buildings are ripped to be shops. No public venue exists in the community, and the trees around the buildings and roads are almost the only green. There you can see a variety of wires and cables mingled, billboards disorderly, itinerant traders gathered and garbage piled everywhere, the environment is very bad. Non-motor vehicles parked everywhere, some of the roads's one-side is full of parked vehicles, leading the fire engines can not pass and planting a significant security risk.

The Xue mansion in Simaqiao district is the representative of the history of the courtyard, "Xue mansion" is one of the "historical buildings worthy protection" in Chengdu. Xue mansion's building area is 280.5 square meters and it has Chengdu rare "true antique" - Shuanma stone and brick arches, its history can be traced back to the Republic of China. There are two courtyards surrounded by more than 20 Chuandou style brick bungalow. Central west courtyard has an old tree named huangjuelan, whose canopy almost obscures over the entire courtyard and the house is full filled with the feeling of old Chengdu. However, the house is rented to be teahouse for a long time, then lack of ongoing maintenance and repairs, so the house is serious damaged and its current situation is not optimistic.

In addition, there also are a certain number of low shanty buildings, whose living conditions are even worse. Taking the yard named number 276 in Jiefang Road as an example, it is said that the cottages in this yard have been built more than 100 years, and so far more than thirty households in the yard are only able to use dry toilets, with no flush toilets, showers and other basic sanitation. In addition, there are some cottages originally built as temporary units, but afterward the unit housing can not meet the people's demand so they have been used until now. Their space is small and crowded, and is also lack of living facilities. It's common to see a family liveing in a crowded house with kitchen seting up the channel and they also build housing everywhere at will to meet their living demands. The house will leak everywhere at rainy days and make the use of fire power extremely unsafe.

Simaqiao district also have a small amount of new high-rise residential community named Taijibeijin, etc., they have such a good residential environment and complete supporting facilities.

\section{Community Living}

The multi-residential buildings in Simaqiao district mostly are dormitories of factory and enterprise. It's common to see the two buildings side by side are classified into a group, and plus iron gate outside and guard room inside. So a internal relatively safe narrow small courtyard has formed. The courtyard is quiet and trees are flourish and the flavor of life is very strong. Neighbors are mostly colleagues, so the relationship between neighbors are relatively harmonious.

But due to poor living conditions and low-level industry formats and other reasons, the young people mostly outflow and aging is serious. The community center constructed by Simaqiao Street Office opens in a few time due to the lack of professional operations team and continued investment funds, the most common recreational activity for community residents is playing mahjong.

Simaqiao district due to lack of necessary public cultural facilities, so that it is common to see the first floor of the buildings were ripped to be mahjong shops. Taking Sichuan Construction community as an example, which has an east-west trunk road and its each side is full of mahjong sheds built by colourful plastic sheetings, not only took most of the road space, but also blocked the passage for fire safety, and the street is also called "mahjong street" by surrounding residents.

\section{Simaqiao District Urban Regeneration Strategies}

\section{A. Teasing Urban Tissue \& Building Urban Axis}

1) Urban Roads. Jiefang Road's regeneration should take the following aspects, including renovating and widening the roads, optimizing pedestrian space, improving the quality of green space, transforming the street facade, adding cultural landscape sketch and Strengthening traffic management. Updated Jiefang Road not only gets a greatly enhanced transport capacity and also will become a road landscape axis which is available for public retirement and is full with memories of Chengdu .

Taking the west side of Jiefang Road as an example, tearing down specific buildings near to Jiefang Road in appropriate position, can not only form the channel contacting Jiefang Road and Shengxi River, but also as a node connecting the inside and outside lanes, which breaking the continuity of the buildings along the street. Through increaseing the choices when walking to enhance the permeability of the city, making the city safer. In this case, combining marine close to water to form a small business or leisure plaza, adding landscape works such as masses fitness facilities, seating and celebrity sculpture, in order to heighten the district's cultural and casual atmosphere.

2) Urban water system. Make full use of the original plan set aside land for irrigation canals, built landscape waterways at superficial level, build marine close to water and cultural 
landscape gallery along waterway, reproduce the style of urban water system should be, form landscape axis to disperse a part of the crowd, reduce traffic pressure on trunk roads. Taking Shengxi River as an example, first remove the illegal structures on the river cement cover, and restore 13-meter-wide ribbon planning land, reserve the tall trees as could as possible, and design the landscape waterway according to the terrain. The waterway is about 2 kilometerswith a width of 2-3 meters and a depth of about 0.3 meters. Both sides of the waterway are plants, marine and small commercial buildings.

Updated Shengxi River and Zhuantouyan River will be two landscape axises of the city, attracting people and guiding all types of people gathered here, so people can experience the city recreation, courtyard dining, fashion and culture in the environment, at the same time, the two landscape axises enhance the permeability of the district, disperse a part of the crowd, reduce traffic pressure on trunk roads.

\section{B. Optimizing the Space Structure \& Extending the Space Form}

1) Open Space. Clearing illegal structures to make space for street greenbelt and small garden. In order to increase the green of unit area, it is supposed to plant shrubs with trees in groups to make the use of green extended to sky. Street greenbelts distribute with a reasonable service radius, and form the open space structure of point-combine-line with three ribbon landscape axises.

2)Historic Buildings. Carrying out systematic investigation and carding for historical buildings in the district, then retaining and repairing architectural forms in different times and styles. Taking the regeneration of Xue mansion as an example, we should set about from three aspects, such as protecting architectural form ,exchanging building function and controling features of buildings around, to be built as "Chengdu Folklore Museum", focusing on the symbiotic culture and practical features, historical heritage combined with the services of modern life .

3)Courtyard Form. The courtyard form of "big yard surround small yard" exists in the multi-storey communities of Simaqiao district, with a strong flavor of eighties of last century, and has become a common memory of the residents in Simaqiao district. In the regeneration of Simaqiao district, it is supposed to extend the courtyard form, and renovate the courtyards form four aspects, such as adding public facilities, tearing down illegal structures, improveing building facade, planting plants, adjusting ground parking and so on, to match with modern life and urban style.

\section{Leveraging Economic Leverages of Urban Regeneration. \\ 1) Using PFI Way to Promote the Development of Public} Utilities. In the urban regeneration of Simaqiao district, the way of PFI can be used to solve the problem that the community center seldom opens. Opening daily the dance rooms, reading rooms and network classrooms, organizing regular monthly re-employment training and other good for residents measures as a condition of the transfer, then transfer the right to operate the community center to private companies, and private companies can make a reasonable profit by renting the classrooms and providing supporting for community activities.

2)Using BOT Way to Promote the Transformation of Decrepit and Old Houses. In the urban regeneration of Simaqiao district, should take the way of BOT for some cottages which are unable to meet the basic living demands and unsuitable for renovation. For example, private companies and residents sign a long-term rental contract renting the house for several years at one time, then private companies put money to carry out construction for the house. After construction, the house is used to commercial activities to make a reasonable profit. At the same time, private companies give the original residents dividends annually by contract and give the right to use the house to residents after the rental housing contract becoming due.

\section{Persueing Tiny Cycle Renovation Mode}

At first, the urban regeneration of Simaqiao district should combin with the nature of the land, roads division, construction quality and other conditions, divide the district into several transformation units, then start the detailed research for each unit. Including four aspects, such as residents life and living structures, land use, housing quality and infrastructure. Then carefully develop transform remediation program. In the program development process, listen to the demands of the residents, with full respect for the wishes of the residents.

\section{Summary}

Urban regeneration is a complex system engineering, the urban regeneration strategies of Simaqiao district involve many aspects, such as political, economic, social, cultural, ecological, etc. It is an innovative exploration facing strategies of old city revolution. We hope that with this article we can provide a favorable reference for old city renovation in future.

\section{References}

[1] Q.C.Pan. The Origin of the Jiefang Road. Bashu local Chronicles. 2009(4): 7-8.

[2] Matsunaga Yasumitsu (Japan). The New Trend in Urban Design. China Building Industry Press, 2012: 187-198.

[3] Q.Zheng, B.Lv, X.H.Tan. Patterns and Inspiration of the Culture -led Urban Regeneration Overseas. Urban Planning International. 2013(1):63-68.

[4] S.N.Liu, H.S.Shan, Z.K.Chang. Urban Renewal Case Studies. China City Press. 2012:126-134.

[5] L.Y.Wu. Beijing Old City and JuEr Hutong. China Building Industry Press. 1994: 186-187. 